\title{
Legal Regulation and Copyright Protection in Internet in Russia and Abroad
}

Lubov Borisovna Sitdikova

Anna Leonidovna Shilovskaya

Maria Alexandrovna Volkova

Renata Romanovna Lenkovskaya

Natalya Alexandrovna Stepanova

Russian State Social University (RSSU), Moscow, Russian Federation

Doi:10.5901/mjss.2015.v6n6p163

\begin{abstract}
The authors analyze one of the most problematic areas in sphere of legal regulation - provision of protection of the copyright in Internet in Russia and in other countries. This sphere remains unregulated because of the difficulties with legal notion of Internet, which remains unclear and also technological aspects of the copyright protection with the means of civil legislation. The conducted analysis allowed to give the notion of Internet and revealed the types of breaches of copyrights in Internet. Authors come to conclusion that the lack of competent judges also leads to the insufficient protection of the copyright in Internet.
\end{abstract}

Keywords: copyright, Internet, copyright protection, literature, science and art, intellectual property.

\section{Introduction}

\subsection{Introduction of the Problem}

The development of society in the modern world is characterized by rapid pace and scale of social change, and this is largely due to the advent and development of new information and telecommunication networks. Today, information and telecommunications network are widely used. However, the copyright to the information flowing into the Internet, do not receive the proper level of protection. This is connected with the fact that this method of transmitting information appeared in Russia relatively recently.

It should be noted that the Internet sphere unlike real legal relations includes unlimited circle of persons having access to the results of intellectual work, and also that at infringement of copyright the Internet-authors and other copyright owners are faced with a serious problem regarding evidence of that the offence was committed by a particular person.

Nevertheless in legal literature, the mechanisms of copyright protection has not been sufficiently researched and discussed. As it is seen in practice, the legal regulation of data protection in information and telecommunication networks is insufficiently developed. While the international community has long and purposefully been engaged in the protection of copyright to solve these problems the way of creating relevant international legislation was elected.

The international Conventions are necessary to establish uniform standards that ensure stability and the rule of law in this sphere of social relations. It is obvious that today there is a need to bring the norms of the legislation of Russian Federation into conformity with international standards of to strengthen the protection of copyright. In this process, the main efforts should be aimed at enhancing and improving the legal framework on the protection of copyrights and the practice of its application.

The research of the mentioned problem must be complex, because this has important theoretical and practical value, as far as promotes the establishment of effective measures of civil-legal protection of copyrights on the Internet. 


\subsection{Importance of the Problem}

Copyright protection for works of literature, science and art on the Internet is among the most difficult problems of civil law regulation. Next we analyze the sources of legal regulation of protection of copyright on the Internet.

The Constitution of the Russian Federation establishes common bases for access to media, freedom of creativity, protection of intellectual property. International acts, Federal laws, regulations and other acts, including the non-normative nature operate on the basis of principles proclaimed by the Constitution. Constitutional norms guarantee freedom of mass information.

In accordance with article 29 of the Constitution of Russian Federation everyone has the right freely to seek, receive, transmit, produce and distribute the information by any lawful means. Article 44 of the Constitution guarantees the freedom of different kinds of creativity, such as literary, artistic, technical, and scientific and others for everyone. This article of the Constitution guarantees the protection of intellectual property.

Traditionally at the international level, copyright protection is divided into two groups:

- adoption of new international agreements without revising of existing multilateral conventions on the protection of rights to works of literature, science and art (produced as the initial or intermediate stage);

- revision of existing multilateral conventions and the adoption of new editions with preserving the action of previous wording (with or without rights to join them after the entry into force of the revised conventions) or the signing of a new international multilateral worldwide agreement that would include a large amount of States parties (Volkov, 2004).

In both cases the precondition of the international legal documents' effectiveness is to increase the number of material law norms in texts of such documents both revised and newly created. Norms contained in international conventions define the circle of those works that are the subject of the international protection.

It should be noted that on the question of the legal force of the Constitution and international legal acts two positions were formed in legal science. One of the authors justify the priority of international acts over the Constitution of Russian Federation pointing at part 4 of article 15 of the Constitution which provides that if an international Treaty establishes rules other than the law of the Russian Federation, the rules of international treaties prevail. Other authors interpret this article in favor of the Constitution. They point out, that the rule that stated in part 4 of article 15 of the RF Constitution, is not applied to the Constitution itself.

In turn, it should be noted that Federal law of the Russian Federation "On international treaties" establishes that international agreements recognized the Constitutional court as not corresponding to the Constitution of the Russian Federation, are not subject to enactment and use in the territory of the Russian Federation. Therefore, the Constitution of the Russian Federation has Supreme legal force in relation to the acts of an international character.

The RF by Government decree acceded to the Berne Convention for the protection of literary and artistic works, to the Convention for the protection of producers of phonograms against unauthorized duplication, to the Word Convention on copyright, etc. the Berne Convention is designed to ensure effective and uniform protection of rights of authors and other right holders on the results of their intellectual work. The need to conclude this international Treaty is substantiated by the lack of clear regulations in this sphere of legal relations, and is also connected with development in social, economic, technical sphere, that places new requirements to States.

The RF Government decree of 11 December 2012, the Russian Federation withdrew the Declaration made upon accession of the Russian Federation to the Berne Convention. World Convention on copyright from 06.09.1952 is one of the fundamental acts governing the issues of copyright at the international level. Under this Convention, each state shall take measures to ensure the protection of the rights of authors and other persons, who hold the copyright on the following kinds of work: literary, artistic, scientific, and written, musical and other works. This Convention guarantees that States parties equal protection of copyright and specifies that States parties must establish the legal rights of citizens of other States parties to the Convention.

Nowadays the Civil code is the important intrastate regulatory act. Part 4 of the Civil code regulates civil relations in this area. Article 1225 of the Civil code refers the works of science, literature and art, computer programs, databases, inventions, useful models, execution, trade names, trademarks and service marks and messages on the air to the protected results of intellectual activity and intellectual property.

In the above-mentioned article of the civil legislation the constitutional provision guaranteeing the protection of intellectual property is mentioned. It should be noted that according to the Russian Civil code intellectual right is obtained at the results of intellectual activity and equalized to them means of individualization (the results of intellectual activity and means of individualization).

The intellectual rights are the objects of legal protection. Intellectual property rights are recognized as exclusive 
rights and may not be transferred, in particular, by contract. Intellectual property is recognized as an exclusive right of the author of intellectual activity results. This means that the transition the ownership of the thing (which expresses the corresponding results of intellectual activity) does not entail the transfer of intellectual rights of the results of intellectual activity (article 1227 of the civil code). However, the civil law provides for the exclusion of transition of exclusive rights to another person. According to section 2 of article 1291 the transfer of the exclusive rights in a work to the purchaser by the owner who is not the author of the work, which has the exclusive right in a work is allowed in frames of purchase of original works (manuscripts, paintings and otherwise) (Sitdikova, 2009).

According to article 1252 of the Civil code, the protection of intellectual rights is accomplished by stating: requirements to admit the right; requirements to stop the actions infringing the intellectual rights; claims for compensation of losses; other.

On the basis of article 1268 of the Civil code, the author is entitled to the disclosure the work by any lawful means. The publication (publication) means the issue of copies of the work, in other words, the publication is expressed in the copies of works in tangible form. However, the publication of the results of intellectual activity creates a number of problems. This is due to the fact that the objects of copyright become available to an unlimited circle of users of the Internet. There is an actual lack of the control over the further use of the information. The publication of the results of intellectual activity and means of individualization equated to them, make threats for their subsequent unauthorized use.

From the regulatory legal acts regulating the activities of public authorities in this field it is important to note the presidential Decree "On the Federal service for intellectual property", as well as the regulations on the Federal service for intellectual property

\subsection{State Hypotheses and Their Correspondence to Research Design}

Today the problem of effective protection of copyright on the Internet is relevant not only for Russia but also for other States. Unfortunately, sufficient attention has not been payed to this problem, and therefore, the issue of protection of authors ' rights on results of intellectual activity in the information and telecommunications network remains open. As the result the development of the network slows significantly, the lack of real protection more withholds authors from publication of material on the Internet.

Currently, no national system of law and open infrastructure information networks (OIS) do not provide guaranteed protection of users' information. Information obtained from the Internet or sent via the Internet can be distorted, fabricated, read and distributed without the knowledge of the authors. The uncontrolled use of encryption tools can make the Internet a perfect environment of exchange of criminal information (Kvantaliane, 2013).

In the Russian Federation today the attention is paid not as much on copyrights in the Internet, as on the rights and interests of man and citizen to freely search and receive information. A range of legal acts adopted in recent years were aimed at removal of the information detrimental to the health and development of children. In particular, the changes were introduced into the Federal law "On mass media". According to changes, at violation the requirements of the Federal law "On protection of children from information harmful to their health or development", the distribution of informational products may be prohibited by court on receipt of the authorized body of the relevant application. A number of legal acts aimed at regulating legal relations in the sphere of information and information technology were adopted. However the abovementioned legal act does not regulate the legal relationship arising from the legal protection of results of intellectual activity and equated to them means of individualization.

Both the legislation of the Russian Federation, and the legislation of other States in the field of the Internet is at an early stage of development. Important normative documents of the European countries in the field of Internet are the documents of the European Parliament and of the Council of Europe. These are "Directive concerning the processing of personal data and the protection of private interests in telecommunications", the draft Directive On certain legal aspects of electronic Commerce in the internal market". These are important normative documents regulating legal relations in the Internet from the position of the informational exchange and e-Commerce. These acts provide legal regulation of the issues of security, privacy, telecommunications, consumer (a user of a telecommunication network) rights, etc. (Chubukova \& Elkin, 2007).

An important precedent in foreign legal regulation in the sphere of the Internet is the German "Multimedia law". German lawmakers unlike the U.S., laying the responsibility for the content provided by a third party, service providers. Here in the imperative provider prescribes the obligation to block "illegal" information (Stepanova, 2014).

Legislation of other countries, particularly Australia, Canada, Denmark, Italy, Luxembourg, Malaysia, South Korea, is at the stage of drafting of legislation in this area.

One should pay attention to some problems of protection of honor and dignity of authors on the Internet. Protection 
of rights and interests of authors on the Internet from negative information today is a priority direction of state policy in this area (Palamarchuk, 2010). Issues of data protection of individuals from violation by posting information discrediting the honor and dignity on the Internet, compounded by the fact that, for example, sites are not subject to mandatory registration as mass media (Tatarinova, 2013).

As noted by Sitdikova, "...the problems of illegal access to personal information of the authors in the Internet also remain open". These problems associated with infringement on the Internet at the international level UN, are resolved. In particular, the UN is working on many aspects of information security problems. 4 December 2000 and 19 December 2001, the General Assembly approved moving the U.S. and other developed countries resolutions 55/63 and 56/121 under the title "combating the criminal misuse of information technologies" aimed at creating a legal framework for this purpose. On 20 December 2002, the General Assembly adopted without a vote resolution 57/239 on "creation of a global culture of cyber security" (GCC), co-author of which Russia also become (Kvantaliane, 2013).

The main objectives of this cooperation consist in solving problems related to crisis management and planning, information exchange, expansion of relations between States and between individual ministries and departments for the purpose of harmonization of national legislations and establishment of the common efforts to combat terrorism.

The conducted analysis shows that, both in Russia and abroad legal problems of copyright protection are quite relevant. The main constraints are the lack of effective legislation, an effective mechanism of control over the use of information on the Internet, the application of certain rules of law in the application of sanctions, the identification of specific individuals who have violated the rights of authors. The absence of a specific legal mechanism, both at the international and at the domestic level, slows down the development of the Internet segment. This suggests that this sphere extremely needs legal regulation.

The conducted analysis of normative-legal acts regulating the issues of copyright on the Internet, leads to the conclusion that legal relations on the Internet are largely dispositive in nature than the relationship between the state and the authors. We are talking about the fact that currently effective system of state control on the Internet for identifying copyright violations, and also the procedure for violation of the rights of authors has no clear legislative regulation (Bliznets, Leontjev, 2011).

In Russian legislation there is no legal definition of "Internet". In this regard, the authors propose the definition of the Internet as a technological system for general use, enabling the processing and sharing information about environment through communication lines by means of computing technique.

The abovementioned shows that at present the legal regulation of copyrights in the Internet is at an early stage of development. Effective legal mechanisms aimed at protecting copyrights $n$ the Internet are lacking both in Russia and abroad.

Constitutional guarantee of human rights and citizen protection in sphere of copyright in general should be ensured by efficiency of measures aimed at the responsibility for copyright infringement in the Internet. On the one hand the sanctioning of Internet users who violates copyright law ensures the restoration of the rights of authors and other copyright holders, on the other - creates favorable conditions for further development of information technology and intellectual activity (Volkova, Sitdikova, Starodumova, Shilovskaya, 2015).

Article 1301 of the Civil code provides for liability for violation of the exclusive rights on a work. According to this article in case of infringement of exclusive rights on a work the author or other right holder may require the payment of compensation instead of damages in amount of from 10 thousand to 5 million (the final amount of compensation is left to the discretion of the court), or in double amount of copies of the work or the cost of the right of use of results of intellectual work. In this case the price is determined by market price usually charged for the lawful use of the work.

Judicial practice in Russia in cases of protection of intellectual work results to a greater extent faced difficulties of legal norms conflicts. It is connected with the fact that the development of the intellectual property institution in information and telecommunication networks is new for our country, but is also connected with the lack of a separate legal regulation of the activity in Internet, the legislative base regulating copyright issues is developed insufficiently, there are no special qualifications for judges on trials concerning protection of the right on work in the Internet. All this is the result of a weak judicial treatment of disputes in this area.

\section{Method}

During the study the authors relied upon general and private methods of cognition: historical, legal, formal-legal, comparative legal, sociological and others. The main method is a system-structural which helped to reveal the ways of protection of the copyrights.

The combination of legal, historical and comparative legal methods allowed us to identify the specifics impact of 
the historical conditions at the development of intellectual law, legal regulation of it define groups of relations that are included in the intellectual law Internet.

Formal legal method made it possible to analyze legal rules governing intellectual rights and copyright protection in

On the basis of the sociological method, grounded conclusions, suggestions and recommendations based on specific information obtained from official sources, materials, periodicals, Internet resources, standards, legal-reference systems, and the media.

\section{Results}

Summing up, it should be noted that in Russia the amount of trials involving the use of copyrights in Internet is rather small. This suggests that civil law does not sufficiently regulate the possibility of claiming to the court in frames of civil procedure. Today also there is no codified act, comprehensively regulating the protection of copyright in Internet.

The analysis allowed to identify the ways of copyright infringement by using the ideas of authors and other right holders of the works, as well as by using various computer programs, including preventing the identification of the IP address. We concluded that the new look in the author's works, in particular, in science and in art has a totally new meaning, a new idea. But Internet users taking a positive norm of civil law utilize the ideas of the authors of works with their own names, but changing the content of texts, which leads to substantial copyright infringement. Also it is concluded with the lack of competent judges specializing on the issues of the intellectual work results protection that seriously impedes the realization of human rights and citizen protection of copyrights.

The rationale is that, first, the Internet is a new institution in Russia, in this regard, there are difficulties in the conceptual framework, the complexity in the correct application of legal acts regulating this sphere of relations. Secondly, the current minimum of judicial practice often leads to making wrong decisions. The creation of intellectual property courts, on the one hand, will create qualified personnel in the judiciary and will significantly increase the number of appeals to the courts in connection with copyright infringement on the Internet.

In considering the question of liability for copyright infringement in Internet, it is concluded that in article 1301 of Civil code, establishing the right of authors to recover the amount of damages, contains certain restriction on the amount (from 10 thousand to 5 million rubles). In turn, this suggests that the issue of copyright protection in civil proceedings in the amount of less than 10 thousand rubles remains open. In this regard, to establish the minimum amount of damages in the civil law is unfounded.

Analysis of civil legislation and judicial practice shows that legal cases involving the use of copyright on the Internet in Russia is rather small. This suggests that civil law does not sufficiently regulate the possibility of recourse to the court in a civil matter (Zolotareva, 2014).

\section{Discussion}

In legal literature the mechanisms of copyright protection has not been sufficiently investigated. As pointed out by E. P. Gavrilov, "...note that the active development of the legislative base in this area will lead to the real possibility of intellectual property rights protection" (Gavrilov, 2012).

The prospect of further improvement of legal regulation of this activity is the creation of the court for the protection of intellectual property. With this proposal for the establishment of this court was made by Prime Minister Dmitry Medvedev at the international forum "Anticounterfeiting-2012". As noted by Dmitry Medvedev "...the lack of an effective mechanism of copyright protection reduces the investment attractiveness, and as a consequence the standard of living in the country. Today there is urgent need for creation of new international mechanisms, as recently has changed the market for the protection of phonograms and the overall market for music sales, therefore, a significant portion of the companies that produce CD and DVD do not get enough profit, which was the main reason - the possibility of downloading content from the Internet and piracy (Umasheva).

It should be noted that the lack of competent judges in Russia on the issues of protection of results of intellectual work seriously impedes the realization of the rights of man and citizen. The rationale is that, first, the Internet is a new institution in Russia, in this regard there are difficulties in the conceptual framework, the complexity in the correct application of legal acts regulating this sphere of relations. Secondly, the current minimum judicial practice often leads to making wrong decisions.

The creation of intellectual property, on the one hand, will create qualified personnel in the judiciary and will significantly increase the number of appeals to the courts in connection with copyright infringement on the Internet. 
Currently there is also a view that the legal protection of copyright on the Internet cannot be ensured. The reason for this is the lack of restrictions on free copying, as well as the difficulty of maintaining control over the use and copying of the results of intellectual labour. The essence of offenses in the field of copyright on the Internet is the same as in traditional relationships, as well as protection against abuse is implemented the same methods provided for by the Russian legislation, including the same judicial civil proceedings (Pogodina, Sminova, 2013). The only important difference resolution of legal problems on the Internet is the lack of ability to provide evidence of copyright infringement. The burden of proof of violations of the rights of authors and other copyright holders lies with them. So before you disseminate the results of intellectual work on the Internet, they need to take certain additional steps to protect their rights (Liepkes, 2006).

In accordance with article 1302 of the Civil code, the court may prohibit certain actions (for example, the manufacture, sale, import, reproduce and otherwise use) the defendant or other person (not recognized by the offender, but in respect of whom there is reason to believe that the person is an infringer of copyright) in order to introduce copies of the infringing work in civil turnover. It should be noted that in respect of the infringing works, the court may impose a fine on all instances or for materials and equipment intended for the manufacture or reproduction of such works.

In accordance with the Code of administrative offences the illegal use of counterfeit copies of works or phonograms authors and other rights holders through the importation, sale, rental, etc., to generate income or if false information about the manufacturers, the owners of copyright and related rights, places of production, on the copies of works or phonograms, shall entail imposition of a fine.

The Criminal Code in article 146 provides for liability for violation of copyright and related rights, which prohibits the assignment of authorship, i.e. plagiarism, the result of which is causing major damage to the copyright holder.

The Civil Code in article 1301, establishing the right of authors to recover the amount of damages, contains certain restriction on the amount (from 10 thousand to 5 million rubles). In turn, this suggests that the issue of copyright protection in civil proceedings in the amount of less than 10 thousand rubles remains open. In this regard, to establish the minimum amount of damages in the civil law is unfounded

\section{References}

World Convention on copyright: of 6.09.1952 (ratified by the Resolution of the Government of the Russian Federation of 03.11.1994 № 1224) .

Constitution of Russian Federation of 12.12.1993 r.

Federal law On international treaties of 15.07.1995 \# 101.

Federal law On protection of children from information harmful to their health or development of 29.12.2010 г. \# 436-Ф3.

Federal law On amendments to different legal acts of Russian Federation in connection with the adoption of the Federal Law On protection of children from information harmful to their health or development of 21.07.2011, \#252.

The Law of Russian Federation On mass media of 27.12.1991 \#2124-1.

The Civil Code of Russian Federation. Part 4. of 18.12.2006 r. \# 230.

The Code of Administrative offences of the Russian Federation of 30. 12. 2001 г. № 195-Ф3.

The Criminal Code of the Russian Federation of 13.06.1996 r. № 63.

Resolution of the Government of the Russian Federation "On the accession of Russian Federation to the Berne Convention for the protection of literary and artistic works (edition of 1971); World Convention on copyright (edition of 1971) and additional protocols 1 and 2, the Convention for the protection of producers of phonograms against unauthorized duplication of 1971" of 3.11.1994 r. $\# 1224$.

Resolution of the Government of the Russian Federation On the Federal Service for intellectual property of 21.03.2012 \# 218

The Decree of the President On the Federal Service for intellectual property of 24.05 .2011 г. \# 673

Bliznets I.A., Leontjev K.B. (2011) Copyright and the related rights: textbook. M: Prospect. P. 278. Moscow.

Chubukova S.G., Elkin V.D. (2007) Bases of legal informatics (legal and mathematics bases of informatics): textbook. M: Contract C. P. 51

Gavrilov E.P. (2012) About the codification of the legislation on the intellectual property. Bulletin of the Supreme Arbitration Court (Vol.10, p. 94-96).

Kvantaliane I.E. (2013) Problems of deterrence and prevention of threats in international informational sphere. Actual problems of humanitarian and natural science. Vol 3 (50). P. 196-197.

Liepkes A.M. (2006) Legal questions of the use of author works in Internet. Doctoral dissertation (P.109).

Palamarchuk A.V. (2010) Protection of exclusive rights for the results of intellectual activity in Internet. Law Vol. 7. pp. 16-18.

Pogodina I.V., Sminova A.O. (2013) Judicial protection of the intellectual property from the breaches in Internet. Law of Intellectual property. (Vol. 4. P. 29).

Sitdikova, L. B. (2009). Legal regulation of relations in the sphere of provision of information and consultancy services in the Russian Federation. Thesis abstract (p. 12). 
Sitdikova, L.B. (2008). Legal nature of Internet services. Russian Law: theory and practice. № 2. P. 203-207.

Stepanova I. (2010) Problems of responsibility for the breach of copyright in Internet. Copyright and related rights. Vol. 10. (P.26-33).

Tatarinova L.F. (2013) Problematic aspects of honor and dignity protection from offences in global communication nets. Actual problems of humanitarian and natural science. Vol 3 (50). (P. 206).

Umasheva I.M. Vesti FM [Electronic source]. - URL: www.radiovesti.ru.

Volkov O.U. (2004) Russian and word problems of legal regulation in Internet. Sourcebook of the IV International scientific-practical conference "Legal reform: problems, collisions, trends of development"(P.28-29).

Volkova M.A., Sitdikova L.B., Starodumova S.J., Shilovskaya A.L. (2015). Legal problems of the information services implementation in Russian civil law. Review of European Studies, Vol. 7, No.6, 243-271. http://dx.doi.org/10.5539/res.v7n6p273

Zolotareva A.E. (2014) The analysis of the Intellectual rights Court activity. Actual problems of Russian legislation. Vol 8. (P. 39-46). 